VIII ${ }^{\text {èmes }}$ Journées Nationales Génie Civil - Génie Côtier, Compiègne, 7-9 septembre 2004

\title{
Sea level rise and its consequences on coastal environment
}

\author{
Abhay K. Shrivastava ${ }^{(a)}$, Daniel R. Levacher ${ }^{(b)}$ \\ ${ }^{(a)}$ Chercheur Invité, ${ }^{(b)}$ Professeur, \\ M2C GRGC UMR 6143 CNRS, 24 rue des Tilleuls, 14000 Caen, \\ FRANCE, (abhay.shrivastava@geos.unicaen.fr).
}

\section{Résumé}

On s'attend à ce que le niveau de la mer relatif monte entre $0.09 \mathrm{~m}$ à $0.88 \mathrm{~m}$ avec le changement de climat prévu. Par conséquent, l'environnement côtier sera sévèrement affecté. Avec l'extension démesurée des régions côtières, il est important que les acteurs politiques et les aménageurs du littoral comprennent ces changements pour les incorporer aux futurs plans de développement du secteur côtier. Une étude de cas comme celle de Rochefort, dans le secteur de delta de Rhône est présentée.

\section{$\underline{\text { Abstract }}$}

Relative sea level is expected to rise between $0.09 \mathrm{~m}$ to $0.88 \mathrm{~m}$ with the predicted climate change. As a consequence, coastal environment will be severely affected. With the unprecedented growth of the coastal regions, it is important that policymakers and coastal managers understand these changes to incorporate them into future developmental plan of coastal area. A case study of Rochefort, Rhône delta area is presented.

Mots-clés: Niveau marin, changement climatique, aménagement côtier

Keywords: sea level rise, climate change, coastal planning

\section{Introduction}

Throughout the geologic time scale, changes in climate has affected the coastal environment and will continue to do so in the future. Since the Last Glacial Maximum (LGM) about 20,000 years ago, the sea level has risen over by $120 \mathrm{~m}$ at locations far from present and former ice sheets. Based on the tide gauge data, the rate of global average sea level rise during the $20^{\text {th }}$ Century is in the range between 1.0 to $2.0 \mathrm{~mm}$.yr- 1 and the average sea level rise in the $20^{\text {th }}$ Century is larger than $19^{\text {th }}$ Century (IPCC, 2001).

With the projected increase in sea level rise due to thermal expansion of water with the projected increase in the global temperature, it is important for coastal managers and the policymakers to understand these changes, in order to integrate these changes in the future developmental plans for coastal regions. Sea level rise will affect all facets of coastal diversity. Human activities and alterations have made coastal resources more vulnerable to climate change - induced processes, such as accelerated sea level rise, alteration of rainfall patterns and storm frequency or intensity, and increased siltation. Coastal land, including buildings, transportation infrastructure, and recreational facilities, is vulnerable to inundation and increased erosion as a result of climate change (NOAA, 1998).

People prefer beach property, either for its aesthetic beauty or as a second home. However, as the Hurricane Andrew in the USA showed that the insurance industry paid out in excess of US\$ 20 billion in Florida and Louisiana states, agreed that many of the damages were due to poor construction of infrastructure and buildings, these costs could be reduced or 
prevented by making better decisions about the location and type of development in coastal areas.

\section{$\underline{\text { 2.Sea level rise }}$}

Average sea level over the oceans has not been constant throughout the earth's history, and it is changing slightly today. Global sea level was about $100 \mathrm{~m}$ lower at the peak of the last ice age, about 18,000 years ago. During the geologic past, there has been repeated variations from present sea level of more than this amount during times of intense glaciation and during periods in which earth was free of ice. During the whole period of human civilization, however, the average sea has been roughly as it is today.

Tide gauges measure sea level variations in relation to a fixed position on land and thus record "relative sea level” (RSL). RSL at any particular point varies over time and space. The direct causes of these variations include vertical motion of land to which tide gauge or other measuring device is attached, and changes in volume of sea water in which the gauge is immersed. Difference in atmospheric pressure, water runoff from land, winds, ocean currents, and the density of sea water all causes spatial and temporal variations in sea level in comparison to the "geoid" (the surface of constant gravitational potential corresponding, on average, to the global mean sea surface). An atmospheric pressure differential of 1 millibar is equivalent to a sea level difference of $1 \mathrm{~cm}$. Variation in the runoff of large rivers can result in local sea level changes of as much as $1 \mathrm{~m}$. In exceptional circumstances, in the North Sea, along the Chinese coast, and in the Bay of Bengal, sea level may rise by $5 \mathrm{~m}$ or more in a "storm surge." These changes are generally no more than a few days in duration. Both irregular and seasonal changes in temperature or salinity of the upper ocean layers cause expansion or contraction of water volume. These relatively short-term changes in sea level may persist for a few days, several months, or even several years, and their magnitude may be as much as 5 to $15 \mathrm{~cm}$ (NRC, 1992).

Several studies of various periods during the last 100 years are in general agreement that mean sea level is rising. Estimates range from about 0.5 to $3.0 \mathrm{~mm}$ per year. Most recent studies show similar or slightly higher estimates, ranging from 1.15 to $2.4 \pm 0.9 \mathrm{~mm}$. There are many sources of errors common to all these studies: $i$. They all use the same common data set; ii. The data set is biased in favour of northern Europe, North America, and Japan, and finally and probably the most important iii. The difficulty in removing the vertical land movements from the data set.

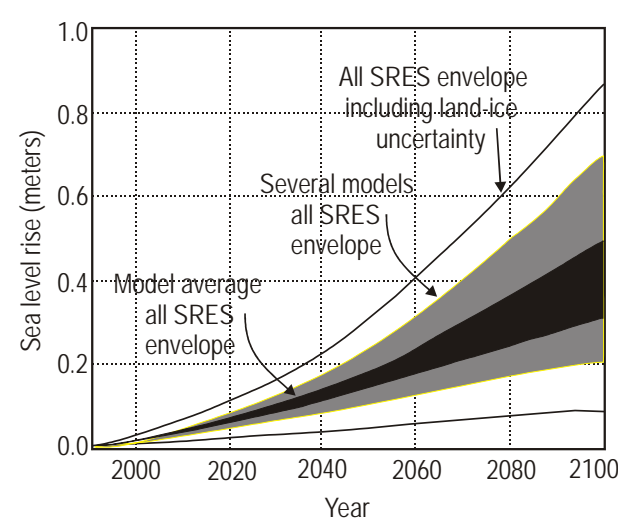

Figure 1. Projected sea level rise due to climate change. 


\subsection{Effects of sea level rise}

Increase in the greenhouse gases is expected to warm the climate. The globally averaged temperature is projected to increase by 1.4 to $5.8^{\circ} \mathrm{C}$ over the period 1990 to 2100 (IPCC, 2001), as a result the sea level is expected to rise between $0.09 \mathrm{~m}$ to $0.88 \mathrm{~m}$ (Figure 1). This rise in sea level would affect the wetlands and lowlands, result in the acceleration of the coastal erosion, will exacerbate coastal flooding, will threaten coastal structure, raise the water table and increase the salinity of rivers, bays and aquifers.

Coastal marshes and swamps are generally located between highest tide of the year and mean sea level. Because they collect sediment and produce peat upon which they can build, most wetlands have been able to keep pace with the past sea level change. However, with the continuing urbanization of the coastal areas, people build structures just above the marshes, the increase in sea level will put a squeeze on these wetland between built structures and the estuaries which will result in the reduction of production of organic materials which is essential for estuarine ecosystem.

Coastal barriers are generally long narrow islands and spits, with ocean on one side and the bay on the other. Typically, the ocean front block of an island ranges from $2 \mathrm{~m}$ to $4 \mathrm{~m}$ above high tide, while the bay side is generally less than a meter above high water. Furthermore, the erosion threatens the high parts of these islands, and is viewed as a more immediate problem. The shape of a beach profile is determined by the pattern of waves striking the shore, and generally, the visible part of the beach is much steeper than the underwater portion, which comprise most of the active "surf zone". While inundation alone is determined by the slope of the land just above the water, Bruun (1962) showed that the total shoreline retreat from a rise in sea level depends on the average slope of the entire beach profile.

Coastal area would become more vulnerable to flooding due to mainly four reasons: i. A higher sea level would provide a higher base for storm surges to build upon; ii. Beach erosion would leave particular properties more vulnerable to storm waves; iii. Higher water would reduce the coastal drainage and hence increase the risks of flooding due to rainstorms; and iv. a rise in sea level would raise water tables.

Many coastal areas are protected with levees and seawalls, and would thus not necessarily experience inundation, erosion or flooding. However, these structures have been designed for current sea level. Higher water levels would threaten the integrity of these coastal structures because the higher flood levels might overtop them and also because the erosion underneath them could undermine them (NRC, 1987; Titus et al 1991).

Finally, a rise in sea level would enable saltwater to penetrate further inland and upstreams in rivers, bays, wetlands and aquifers, which would be harmful to aquatic plants and animals, and would threaten human uses of water.

Table 1 adapted from the IPCC's Summary for Policymakers (2001) shows the estimates of confidence in observed and projected changes in extreme weather and climatic events. With the expected climatic change, it is expected, for example, that the precipitation events will become more intense which will lead to the increase in the severity and the intensity of the floods. Similarly, increase in tropical cyclone peak wind intensities will lead to increase in the frequency and the intensity of the storm surges of which policymakers and coastal managers need to provide for in their future developmental plans. 
Table1: Estimates of confidence in observed and projected changes in extreme weather and climate events. (Adapted from IPCC, 2001).

\begin{tabular}{|c|c|c|}
\hline $\begin{array}{l}\text { Confidence in observed changes } \\
\text { (late half of } 20^{\text {th }} \mathrm{C} \text { ) }\end{array}$ & CHANGES IN PHENOMENON & $\begin{array}{l}\text { Confidence in projected changes } \\
\text { (during the } 21^{\text {st }} \mathrm{C} \text { ) }\end{array}$ \\
\hline likely & $\begin{array}{l}\text { Higher maximum temperatures \& most hot } \\
\text { days over nearly all land areas. } \\
\text { REDUCED WATER RESOURCES }\end{array}$ & very likely \\
\hline very likely & $\begin{array}{c}\text { Higher minimum temperatures, fewer cold } \\
\text { days and frost days over nearly all land } \\
\text { areas. } \\
\text { REDUCED WATER RESOURCES }\end{array}$ & very likely \\
\hline very likely & $\begin{array}{l}\text { Reduced diurnal temperature range over } \\
\text { most land areas. }\end{array}$ & very likely \\
\hline likely, over many areas & $\begin{array}{l}\text { Increase of heat index over land areas. } \\
\text { REDUCED WATER RESOURCES }\end{array}$ & very likely, over most areas \\
\hline $\begin{array}{l}\text { likely, over many northern } \\
\text { Hemisphere mid- to high } \\
\text { latitude land areas }\end{array}$ & $\begin{array}{l}\text { More intense precipitation events. } \\
\text { INCREASE IN THE SEVERITY AND } \\
\text { INTENSITY OF THE FLOODS }\end{array}$ & very likely, over many areas \\
\hline likely, in few areas & $\begin{array}{l}\text { Increased summer continental drying and } \\
\text { associated risks of drought. } \\
\text { INCREASE IN THE SEVERITY AND } \\
\text { FREQUENCY OF DROUGHTS } \\
\end{array}$ & $\begin{array}{l}\text { likely, over most mid-latitude } \\
\text { continental interiors. (lack of } \\
\text { projection in other areas). }\end{array}$ \\
\hline $\begin{array}{l}\text { not observed in the few analyses } \\
\text { available }\end{array}$ & $\begin{array}{l}\text { Increase in tropical cyclone peak wind } \\
\text { intensities. } \\
\text { FREQUENCY AND INTENSITY OF } \\
\text { STORM SURGE INCREASES }\end{array}$ & likely, over some areas \\
\hline insufficient data for assessment & $\begin{array}{l}\text { Increase in tropical cyclone mean and peak } \\
\text { precipitation intensities. } \\
\text { SEVERITY AND INTENSITY OF } \\
\text { FLOOD INCREASES }\end{array}$ & likely, over some areas \\
\hline
\end{tabular}

${ }^{1}$ How water-system/hydrologic cycle will be affected

\section{$\underline{\text { 3.Urbanization of the coastal areas }}$}

With the continued urbanization of the coastal areas and ever more increasing demands of the related industries, the water balance of a coastal aquifer can get affected in several ways, with serious impacts upon human water supplies and coastal ecosystems. Urbanization can also have large impacts upon ground- and surface water quality. The dynamic balance between fresh and salt-water at depth can be altered due increased pumping due to increase in demand from public-water supply, which can lead to shift in position of the interface between fresh and salt waters and possibly cause salt-water intrusion into pumping wells. Furthermore, urbanization can result in the reduction of aquifer recharge rates (and affect the interface position) by increasing the fraction of impervious surface on the landscape. These changes in the water balance not only affect the interface between salt and fresh water at depth in aquifer, but can also affect pond levels, wetland levels, stream flow, and the salinity regime of tidal creek systems (Shrivastava and Levacher, 2004).

Rapid urban population growth, exacerbated by rural to urban migration, is a major developmental challenge for developing countries. In 1950 only $18 \%$ of the people in developing countries lived in cities. In 2000 the proportion was 40\%, and by 2030 the developing world will be $56 \%$ urban (Brockherrhof, 2000). While urban population in the industrialized nations are growing at $0.4 \%$, the average growth rate in the cities of the 
developing world is 2.3\%, with Africa experiencing a rate of $4.2 \%$. The proportion of people living in very large urban agglomerations or 'megacities' (cities with atleast 10 million people) is growing all the time. In 2000, 3.7 percent of the world population resided in cities of 10 million inhabitants or more and by 2015 that portion is expected to rise to 4.7 per cent. Table 2 shows that in 1975 only 5 cities worldwide had 10 million or more inhabitants, of which three were in developing countries. The global number will increase to 21 by 2015, all but 4 of them in developing countries.

Table 2. The growth in Megacities. Note that except four, highlighted, all these cities will be in developing economies.

\begin{tabular}{|c|c|c|c|c|c|c|c|}
\hline \multicolumn{2}{|c|}{1950} & \multicolumn{2}{|l|}{1975} & \multicolumn{2}{|l|}{2001} & \multicolumn{2}{|l|}{2015} \\
\hline city & Pop & city & Pop & city & Pop & city & Pop \\
\hline $\begin{array}{l}\text { 1. New } \\
\text { York }\end{array}$ & 12.3 & $\begin{array}{l}\text { 1. Tokyo } \\
\text { 2. New York } \\
\text { 3. Shanghai } \\
\text { 4. Mexico } \\
\text { City } \\
\text { 5. Sao Paulo }\end{array}$ & $\begin{array}{l}19.8 \\
15.9 \\
11.4 \\
10.7 \\
10.3\end{array}$ & $\begin{array}{l}\text { 1. Tokyo } \\
\text { 2. Sao Paulo } \\
\text { 3. Mexico City } \\
\text { 4. New York } \\
\text { 5. Mumbai } \\
\text { 6. Los Angeles } \\
\text { 7. Calcutta } \\
\text { 8. Dhaka } \\
\text { 9. Delhi } \\
\text { 10. Shanghai } \\
\text { 11. Bunos Aires } \\
\text { 12. Jakarta } \\
\text { 13. Osaka } \\
\text { 14. Beijing } \\
\text { 15. Rio de } \\
\text { Janeiro } \\
\text { 16. Karachi } \\
\text { 17. Metro } \\
\text { Manila }\end{array}$ & $\begin{array}{l}26.5 \\
18.3 \\
18.3 \\
16.8 \\
16.5 \\
13.3 \\
13.3 \\
13.2 \\
13.0 \\
12.8 \\
12.1 \\
11.4 \\
11.0 \\
10.8 \\
10.5 \\
\\
10.4 \\
10.1 \\
\end{array}$ & $\begin{array}{l}\text { 1. Tokyo } \\
\text { 2. Dhaka } \\
\text { 3. Mumbai } \\
\text { 4. Sao Paulo } \\
\text { 5. Delhi } \\
\text { 6. Mexico City } \\
\text { 7. New York } \\
\text { 8. Jakarta } \\
\text { 9. Calcutta } \\
\text { 10. Karachi } \\
\text { 11. Lagos } \\
\text { 12. Los Angeles } \\
\text { 13. Shanghai } \\
\text { 14. Bunos Aires } \\
\text { 15. Metro Manila } \\
\text { 16. Beijing } \\
\text { 17. Rio de Janeiro } \\
\text { 18. Cairo } \\
\text { 19. Istanbul } \\
\text { 20. Osaka } \\
\text { 21. Taiiin }\end{array}$ & $\begin{array}{l}27.2 \\
22.8 \\
22.6 \\
21.2 \\
20.9 \\
20.4 \\
17.9 \\
17.3 \\
16.7 \\
16.2 \\
16.0 \\
14.5 \\
13.6 \\
13.2 \\
12.6 \\
11.7 \\
11.5 \\
11.5 \\
11.4 \\
11.0 \\
10.3\end{array}$ \\
\hline
\end{tabular}

How these megacities will be affected with the expected sea level rise! The potential impact to these megacities due to sea level rise come mainly from two sources: i. increasing risks of flooding and water contamination because of more frequent events like storms and rains; and ii. Increasing risk of flooding because of increasing sea water level with direct impact in case of coastal cities or inland cities that are located on rivers in lowlands.

\section{Mitigation of sea level rise}

Klein et al (2000) have suggested three broad response strategy to the sea level rise. They include:

1. reduce the risk of the event by decreasing its probability of occurrence,

2. reduce the risk of the event by limiting its potential effects, and

3. increase society's ability to cope with the effects of the event. 
And they are termed as protect, retreat, and accommodate, respectively. In the case of protection strategy, the coastal zones are squeezed and hence a decline in natural functions and values are expected, if the soft protection approach is chosen this problem may not arise.

The actual strategy chosen will depend on local and national circumstances, including the economic and ecological importance of the coastline, technical and financial capabilities, and the legislative and political structure of the countries concerned. Although optimum response strategies have yet to be developed, it is likely that a range of responses will be the norm within any country (Bijlsma et al, 1996).

\section{Case History}

The three measures discussed above have been utilized in the case of Rhône delta which is expected to go underwater in the case of sea level rise of $0.5 \mathrm{~m}$. The problem of possible effects related with expected sea-level rise has been addressed in France during the last decade at a governmental level. At the beginning of the 1990's and at the request of the Ministry of Environment, a consulting agency produced a report entitled Climatic changes and sea-level rise, socio-economic assessment of impacts on the French coasts. This included a coloured map, at a 1:1,250,000 scale illustrating the vulnerability of coastal areas to flooding, erosion, and salt intrusion, assuming a $50 \mathrm{~cm}$ sea-level rise. This study also included a summary of the costs derived from such a sea-level rise on beaches, marshes, reclaimed areas and harbours (Paskoff, 2001 and references therein).

Additionally, a detailed case study that of Rochefort-sur-Mer area, on the central part of the Atlantic coast of France, was also carried out for this report. The extensive marshy lowlands surrounding Rochefort-sur-Mer have been largely reclaimed in the course of time, and are known to be prone to flooding when low frequency, high magnitude storm surges occur. In this area, the cost of adaptation to sea-level rise is estimated at around 10 millions FF/year (Paskoff, 2001).

\subsection{Deltaic plain of Rhône river}

In France, the deltaic plain of Rhône river is considered to be the most vulnerable to the impacts of sea level rise. For example, at Marseille, located at the east of the delta, the rate of relative sea level rise is about $+2.1 \mathrm{~mm}$. $\mathrm{yr}^{-1}$, instead of $+1.3 \mathrm{~mm} \cdot \mathrm{yr}^{-1}$, this is due to the natural subsidence that is observed in the area. Sea level of various other locations in France is given Table 3. This is further aggravated, as this on-going subsidence in not compensated by the sediments brought in by the river due to building of several dams upstream. Deltas are normally built by periodic flooding and shifting position of the distributary river mouths. However, the two branches of Rhône river are completely embanked and do not have the ability to shift their positions. Forthermore, the flow of the Rhône has largely been reduced because of increased irrigation upstreams. Rapid erosion of the shoreline, where abandoned sub-delta lobes are located, add to the subsiding trend noted above (Figure 2). The area is not very densely populated and the part of the area belongs to natural reserves (85,000 ha). There is only one small town (Les Saintes-Maries-de-la-Mer) with the total population of 2,000 and their main activity is rice production and animal husbandry, though, salt production and tourism constitute other economic activity of the area. It is expected that with the rise in sea level this salt pan will undergo, it can be abandoned for economic reasons. Also it is worth noting, during the last serious flooding in December 1997, the storm surge of $1.6 \mathrm{~m}$ and the waves height reaching $10 \mathrm{~m}$, the dikes were overtopped and destroyed. 
Table 3: Relative sea-level behaviour along the French coasts .

\begin{tabular}{|c|c|c|c|}
\hline Locality & Time & L-T Trend $^{1}$ & Variability $^{2}$ \\
\hline \multicolumn{4}{|l|}{$\begin{array}{l}\text { France } \\
\text { (Atlantic) }\end{array}$} \\
\hline Cherbourg & 1891-1958 & +0.4 & (1.9) \\
\hline Brest & $1807-1981$ & +0.8 & $(0.5)$ \\
\hline Brest & $1807-1890$ & +0.3 & $(0.7)$ \\
\hline Brest & $1890-1981$ & +1.2 & $(0.8)$ \\
\hline $\begin{array}{l}\text { Les Sables } \\
\text { d'Olonne }\end{array}$ & 1892-1956 & +2.3 & (1.4) \\
\hline La Pallice & 1891-1951 & +3.1 & - \\
\hline Biarritz & $1885-1950$ & +0.4 & - \\
\hline St Jean-de Luz & 1890-1963 & +1.4 & (3.6) \\
\hline \multicolumn{4}{|l|}{$\begin{array}{c}\text { France } \\
\text { (Mediterranean) }\end{array}$} \\
\hline Port Vendres & 1888-1958 & +0.9 & (1.3) \\
\hline Sête & 1888-1961 & +0.3 & $(0.7)$ \\
\hline Port de bouc & 1894-1951 & +2.6 & - \\
\hline Martigues & 1894-1956 & -0.3 & $(0.9)$ \\
\hline Marseilles & $1885-1978$ & +1.3 & $(0.4)$ \\
\hline La Ciotat & 1893-1951 & +2.1 & - \\
\hline Villefranche & 1913-1957 & $(+0.9)$ & (1.4) \\
\hline
\end{tabular}

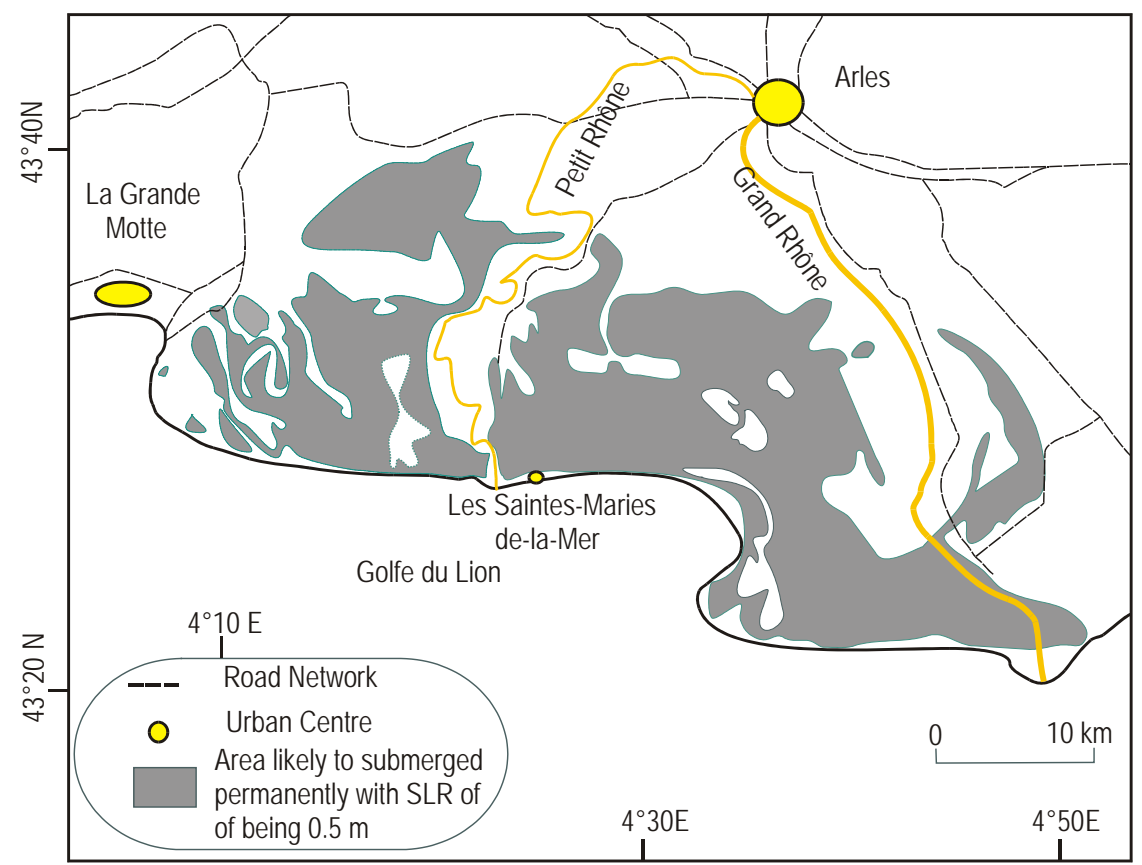

Figure 2. Areas likely to be submerged in the Rhône delta with $0.5 \mathrm{~m}$ sea level rise 


\section{Conclusion}

The sea level rise associated with the global environmental changes in future entails many problems for the humanity. It will be specially severe on the developing and least developing countries where much for the humanity lives, as well as they are the fastest growing. The effect of sea level rise will be felt in many area, and prudent choices have to made depending upon the local circumstances. As shown in the case of Rhône delta area, due to economic reasons, the area could be abandoned or a planned retreat can be devised for the population. These difficulties have to be understood by the coastal managers and policymakers to include them into future developmental plans.

\section{Références}

1.Brockherrhof, M., 2000. An urbanizing world. Population Bulletin, 55(3):3-44.

2.Bruun, P., 1962. Sea level rise as a cause of shore erosion. Jour. of Waterways and Harbor Division, ASCE, 88:117-130

3.Bijlsma, L., C.N. Ehler, R.J.T. Klein, S.M. Kulshrestha, R.F. McLean, N. Mimura, R.J. Nicholls, L.A. Nurse, H. Pérez Nieto, E.Z. Stakhiv, R.K. Turner, and R.A. Warrick, 1996: Coastal zones and small islands. In: Climate Change 1995: Impacts, Adaptations and Mitigation of Climate Change: Scientific-Technical Analyses. Contribution of Working Group II to the Second Assessment Report of the Intergovernmental Panel on Climate Change [Watson, R.T., M.C. Zinyowera, and R.H. Moss (eds.)]. Cambridge University Press, Cambridge, United Kingdom and New York, NY, USA, pp. 289-324.

4.Intergovernmental Panel on Climate Change (IPCC), 2001. Climate change 2001: Scientific Basis. http://www.grida.no/climate/ipcc_tar/wg1/pdf/WG1_TAR-FRONT.PDF accessed on Dec18, 2003.

5.Klein, R.J.T., J. Aston, E.N. Buckley, M. Capobianco, N. Mizutani, R.J. Nicholls, P.D. Nunn, and S. Ragoonaden, 2000: Coastal adaptation technologies. In: IPCC Special Report on Methodological and Technological Issues in Technology Transfer [Metz, B., O.R. Davidson, J.-W. Martens, S.N.M. van Rooijen, and L. Van Wie McGrory (eds.)]. Cambridge University Press, Cambridge, United Kingdom and New York, NY, USA, pp. 349-372.

6.National Research Council (NRC), 1987. Responding to changes in sea level: engineering implications. Washington, D. C., National Academic Press. 148p.

7.National Research Council (NRC), 1992. Policy implication of greenhouse warming: mitigation, adaptation, and the science base. Washington, D. C., National Academic Press. 918p.

8. National Oceangraphic and Atmospheric Administration (NOAA), 1998. Year of the Ocean. Accessed on Dec. 23, 2003. http://www.yoto98.noaa.gov/.

9.Paskoff, R., 2001. Implications of accelerated sea-level rise (ASLR) for France. Proceeding of SURVAS Expert Workshop on European Vulnerability and Adaptations to impacts of Accelerated Sea-Level Rise (ASLR), Hamburg, Germany, June 2000, 47-51.

10.Shrivastava, A. K., and Levacher, D. R., 2004. The role of in situ testing in coastal environmental monitoring, VIII ${ }^{\mathrm{èmes}}$ Journées Nationales Génie Côtier-Génie Civil, Compiègne 2004.

11.Titus, J. G., Park, R. A., Leatherman, S. P., Weggel, J. R., Greene, M. S., Mausel, P. W., Brown, S., Gaunt, G., Trehan, M., and Yohe, G , 1991. Greenhouse effects and sea level rise: the cost of holding back the sea. Coastal Management, 19:171-204. 